\title{
Butter whey and corn steep liquor as sole raw materials to obtain a bioemulsifier from Yarrowia lipolytica for food oil-in-water emulsions
}

\author{
Fabiane Ferreira dos Santos ${ }^{1}$ (D) Karine Marques Lento de Freitas ${ }^{1}$ (D) \\ Adejanildo da Silva Pereira ${ }^{1}$ (D) Gizele Cardoso Fontes-Sant'Ana ${ }^{2}$ (D) \\ Maria Helena Miguez da Rocha-Leão ${ }^{1}$ (D) Priscilla Filomena Fonseca Amaral ${ }^{1^{*}(\mathbb{D})}$
} 1Departamento de Engenharia Bioquímica, Escola de Química, Universidade Federal do Rio de Janeiro (UFRJ), 21941-909, Rio de Janeiro, RJ,
Brasil. E-mail: pamaral@eq.ufrj.br. "Corresponding author.

${ }^{2}$ Instituto de Química, Universidade do Estado do Rio de Janeiro (UERJ), Maracanã, RJ, Brasil.

ABSTRACT: A synthetic medium containing glucose, glycerol, yeast extract (YE), and ammonium sulfate (AS) was compared to several low-cost media in their ability to produce high emulsification index (EI). The goal was to reduce the production costs of an emulsifier with application in food oil-in-water emulsions. To this end, agro-industrial by-products were screened for bioemulsifier production from Yarrowia lipolytica. The statistical analysis showed that the EIs of media containing residual frying oil from palm oil (RFO_palm) or soybean oil (RFO_soy), residual liquid from butter production (butter whey, BWhey) or cheese production (cheese whey, CWhey), supplemented with YE and $\overline{A S}$ were similar to the EI of the synthetic medium. The replacement of YE by corn steep liquor (CSL) also resulted in similar EI, except for RFO_soy. BWhey was tested with CSL without AS and similar EI (66.8\%) was detected in comparison to that of the same medium with $A S(66.3 \%)$. The cell-free broth obtained after Y. lipolytica growth in BWhey+CSL was successfully used to obtain vegetable oil-in-water emulsions indicating its potential application in food products.

Key words: Yarrowia lipolytica, dairy by-product, low-cost medium, emulsification index.

Soro de manteiga e milhocina como únicas matérias primas para obter bioemulsificante de Yarrowia lipolytica para emulsões óleo-em-água alimentícias

RESUMO: O meio sintético contendo glicose, glicerol, extrato de levedura (YE) e sulfato de amônio (AS) foi comparado a meios de baixo custo para produzir alto índice de emulsificação (EI). Para este fim, os subprodutos agroindustriais foram rastreados quanto à produção de bioemulsificante por Yarrowia lipolytica. A análise estatística mostrou que EI de meios contendo óleo de fritura residual de óleo de palma (RFO_palm) ou óleo de soja (RFO_soy), líquido residual da produção de manteiga (soro de manteiga, BWhey) ou da produção de queijo (soro de queijo, CWhey), suplementado com YE e AS foram semelhantes ao EI do meio sintético. A substituição do YE por milhocina (CSL) também resultou em EI semelhante, exceto no RFO_soy. O BWhey foi testado com CSL sem AS e EI semelhante (66,8\%) foi detectado em comparação com o mesmo meio com AS (66,3\%). O meio isento de células obtido após o crescimento de Y. lipolytica no meio BWhey $+C S L$ foi utilizado com sucesso para obter emulsões de óleo vegetal em água, indicando sua potencial aplicação em produtos alimentícios.

Palavras-chave: Yarrowia lipolytica, subprodutos lácteos, meio de baixo custo, índice de emulsificação.

\section{INTRODUCTION}

The food industry is responsible for the production and disposal of large volumes of polluting organic wastes. These materials are usually rich in carbohydrates, lipids, and proteins, making them attractive for several fermentation processes (GUDINA et al., 2016). Thus, in recent years, numerous studies have been carried out using food waste to produce commercially valuable products, such as biosurfactants (LUNA et al., 2016).

Biosurfactants are amphiphilic compounds produced by microorganisms, able to reduce surface and interfacial tension of immiscible solutions (SINGH et al., 2007). Their production and composition are generally conditioned to the composition of the culture medium (SOUZA et al., 2017). The term biosurfactant is used to characterize products that reduce the surface tension between two liquids, while the term bioemulsifier designates products that induce dispersion of undissolved material throughout the liquid; forming and stabilizing droplets of the dispersed phase (UZOIGWE et al., 2015). The interest in these molecules is always expanding because items commonly used in our daily activities, such as pharmaceuticals, personal care, cosmetics and food products, demand surfactant action (FRAGA et al., 2020). The advantage of using biosurfactants over chemical surfactants is their greater biodegradability, compatibility and lower toxicity (PI et al., 2017). 
Although, the interest in biosurfactants is increasing, these compounds do not compete economically with synthetic surfactants. In order to reduce production costs, different approaches can be investigated, such as the use of waste or agroindustrial by-products. Bioconversion of these wastes/ by-products is considered primary importance for the near future because it demands low capital and energy costs and reduces environmental pollution (MAKKAR, 2011).

Currently, there are several waste materials or by-products from industries and commercial establishments available. For example, the spread of fried food consumption has contributed to an increase in the disposal of large amounts of oils and fats. Although, frying oil repeatedly used in homes and businesses can cause severe damages to the environment, it can be converted into high-value products by microorganisms (LIU et al., 2015). Another potential renewable resource for microbial surfactant production is dairy industry by-products, such as butter, cheese, and ricotta whey, which are the residual liquid breaded after butter, cheese, and ricotta production, respectively (MENESES et al., 2020). Cheese whey has many applications, such as commercial products or even biosurfactant production (YILMAZ et al., 2009). However, butter and ricotta whey, as inferiornutritional by-products, have not been tested for many purposes, increasing their incorrect disposal in the environment. Corn steep liquor is another example of an easily available agro-industrial by-product, with high carbohydrate, lipid, and protein contents that have been successfully evaluated for biosurfactant production (LUNA et al., 2013).

A variety of microorganisms can produce biosurfactants, and among them, Yarrowia lipolytica is an especially important specie (AMARAL et al., 2006). Y. lipolytica is a non-pathogenic yeast, classified as GRAS (generally regarded as safe) by the US Food and Drug Administration (FDA) (DARVISHI et al., 2019). It is also a microorganism known to use agroindustrial wastes for bioconversions (LIU et al., 2015).

Previous studies using agro-industrial by-products, such as whey (YILMAZ et al., 2009), fish waste and sugarcane bagasse (MARTINS \& MARTINS, 2018), soybean frying oil (SILVA et al., 2014; MARQUES et al., 2020), peanut oil and corn steep liquor (LUNA et al., 2015), cane oil and corn steep liquor (da SILVA et al., 2017), palm oil refinery waste (RADZUAN et al., 2017) and olive oil extraction waste (RAMÍREZ et al., 2015) report the use of mineral media and other sources of nutrients as supplements for biosurfactant production.
The present study aimed to investigate, through the emulsification index, the potential of food (frying residual oil, cheese whey, butter whey, and ricotta whey) and the industrial (corn steep liquor) by-products as single sources of nutrients for bioemulsifier production by the yeast strain Yarrowia lipolytica IMUFRJ 50682.

\section{MATERIALS AND METHODS}

\section{Materials and microorganism}

Culture medium components used were peptone and yeast extract (Kasvi - PR., Brazil), glucose (Reagen - RJ, Brazil), agar, ammonium sulfate, and glycerol (Vetec - RJ, Brazil), hexadecane (Sigma-Aldrich CO (MO, USA)). Yarrowia lipolytica 583 IMUFRJ 50682 selected from a Guanabara Bay estuary in Rio de Janeiro, Brazil (HAGLER \& MENDONÇA-HAGLER, 1981) was maintained on YPD-agar medium, containing (per liter): $10 \mathrm{~g}$ of yeast extract, $20 \mathrm{~g}$ of peptone, $20 \mathrm{~g}$ of glucose and 30 $\mathrm{g}$ of agar and was stored at $4^{\circ} \mathrm{C}$. Five different agroindustrial by-products were tested for biosurfactant production: residual frying oil (RFO), cheese whey (CWhey), butter whey (BWhey), ricotta whey (RWhey), and corn steep liquor (CSL). RFO had two different origins : one was obtained from a fast-food chain, Brazil Fast Food Corporation, used in Bob's fast food restaurant (Rio de Janeiro, Brazil) to fry potatoes, originally a palm oil (RFO_palm) and the other was supplied by the National Museum (UFRJ, Brazil) restaurant originally a soybean oil (RFO_ Soy). Both were kept under refrigeration at $4^{\circ} \mathrm{C}$. Dairy by-products were donated by the Agroindustry of Instituto Federal de Alagoas and stored in falcon tubes at $-20^{\circ} \mathrm{C}$. Ingredion Brasil donated $4 \mathrm{~kg}$ of CSL that was stored at $4^{\circ} \mathrm{C}$.

\section{Biosurfactant production}

Yarrowia lipolytica cells (IMUFRJ 50682) were transferred to $500 \mathrm{~mL}$ Erlenmeyer flasks containing $200 \mathrm{~mL}$ of YPD medium (yeast extract, $1 \%(\mathrm{w} / \mathrm{v})$; peptone, $2 \%(\mathrm{w} / \mathrm{v})$; and glucose, $2 \%$ $(\mathrm{w} / \mathrm{v}))$, maintained in orbital shaking (160 rpm), at 28 ${ }^{\circ} \mathrm{C}$ for $72 \mathrm{~h}$. These cells were centrifuged $(2,000 \mathrm{~g})$ in a sufficient amount to inoculate $1 \mathrm{mg}$ of the dry weight of cells per $\mathrm{mL}$ of biosurfactant production medium (AMARAL et al., 2006).

Biosurfactant production was carried out in $1000 \mathrm{~mL}$ Erlenmeyer flasks with $500 \mathrm{~mL}$ of production medium containing the agro-industrial by-products, as described by FONTES et al. (2010). The culture medium composed of $0.5 \mathrm{~g} / \mathrm{L}$ yeast 
extract, $10 \mathrm{~g} / \mathrm{L}$ ammonium sulfate, $4 \%(\mathrm{w} / \mathrm{v})$ of glucose and $2 \%(\mathrm{w} / \mathrm{v})$ of glycerol optimized by FONTES et al. (2010), was used as control medium (CTRL). The same yeast extract (YE) and ammonium sulfate (AS) concentrations were used to test the agro-industrial by-products (RFO_palm; RFO_ soy; CWhey; BWhey; RWhey) for biosurfactant production. The liquid medium was sterilized in an autoclave $\left(121^{\circ} \mathrm{C}, 20 \mathrm{~min}\right)$ and then, $10 \mathrm{~g} / \mathrm{L}$ of each by-product was added to the production medium after exposure to ultraviolet radiation for 20 minutes to reduce microbial load. Nor glucose or glycerol was added to these media. The CSL was used to replace YE in the following concentrations: 1.0, 3.0 and $5.0 \mathrm{~g} / \mathrm{L}$, maintaining $10 \mathrm{~g} / \mathrm{L}$ of AS and $10 \mathrm{~g} / \mathrm{L}$ of the agro-industrial by-products (RFO_palm; RFO_soy; CWhey; BWhey; RWhey). The control (CTRL) was prepared with CSL $(1.0,3.0$ or $5.0 \mathrm{~g} / \mathrm{L}), 10 \mathrm{~g} / \mathrm{L}$ of AS, $4 \%(w / v)$ of glucose and $2 \%(w / v)$ of glycerol. The use of CSL $(1.0,3.0$ and $5.0 \mathrm{~g} / \mathrm{L})$ without AS or agro-industrial by-products was also investigated. Ammonium sulfate $(10 \mathrm{~g} / \mathrm{L})$ was tested alone, as well as with the agro-industrial by-products $(10 \mathrm{~g} / \mathrm{L})$ (RFO_palm; RFO_soy; CWhey; BWhey; RWhey). BWhey $(10 \mathrm{~g} / \mathrm{L})$ was tested with CSL $(5.0 \mathrm{~g} / \mathrm{L})$ and no other components. The flasks were incubated for $96 \mathrm{~h}$ at $28^{\circ} \mathrm{C}$ and $250 \mathrm{rpm}$. Samples were collected at $24 \mathrm{~h}$ intervals, centrifuged $(2,000 \mathrm{~g})$ and stored at -20 ${ }^{\circ} \mathrm{C}$ for the analytical procedures.

\section{Analytical procedures}

Cell concentration: Optical density (OD) measurements at $570 \mathrm{~nm}$ converted to $\mathrm{g}$ dry weight (d.w.) cells/L using the equation $O D^{*}$ dilution/0.363 were used to monitor cell growth (AMARAL et al., 2006). The $\mathrm{pH}$ of the cell-free samples was determined by a $\mathrm{pH}$ meter (DIGIMED DM-22), calibrated with standard buffer solutions ( $\mathrm{pH} 4.0$ and 7.0).

Emulsification index - Hexadecane: The emulsification index of cell-free samples from the production medium during fermentation was determined according to the method described by FONTES et al. (2010). One $\mathrm{mL}$ of the cell-free sample and $1 \mathrm{~mL}$ of hexadecane were vortex mixed in a test tube for 2 minutes. Then, the tubes were left to stand for $24 \mathrm{~h}$, and the emulsification index (EI) was calculated by Equation (1).

$E I=\frac{H_{e} * 100}{H_{t}}$

where $\mathrm{H}_{\mathrm{e}}$ is the height of the emulsified layer $(\mathrm{cm})$, and $\mathrm{H}_{\mathrm{t}}^{\mathrm{e}}$ is the total height of the liquid column $(\mathrm{cm})$. The result was expressed as a percentage.
Emulsification index - Vegetable oils: To verify the applicability of the emulsifier produced, an emulsification index with vegetable oils was determined. The procedure adopted was the same as described for "Emulsification index - hexadecane", but using vegetable oils (sunflower, soybean, olive, almond, castor, buriti, coconut and palm) instead of hexadecane. Additionally, $\mathrm{H}_{\mathrm{e}}$ was measured not only after $24 \mathrm{~h}$, but also after 48,72 and $96 \mathrm{~h}$ of tube rest to evaluate the stability of the emulsions.

\section{Statistical analysis}

Statistical analysis was performed with STATISTICA 7.1 software (StatSoft, Inc., Tulsa, OK, USA). The significance of the effects of the variables was statistically verified through analysis of variance (ANOVA) and the comparison between means obtained by the application of Tukey's test and Dunnett. The level of significance was $5 \%(\mathrm{P}<0.05)$.

\section{RESULTS AND DISCUSSION}

Selection of agro-industrial by-products for bioemulsifier production with yeast extract and ammonium sulfate

Biosurfactant production by $Y$. lipolytica was optimized by FONTES et al. (2010) with glucose $(40 \mathrm{~g} / \mathrm{L})$ and glycerol $(20 \mathrm{~g} / \mathrm{L})$ as carbon sources and ammonium sulfate $(10 \mathrm{~g} / \mathrm{L})$ and yeast extract $(0.5 \mathrm{~g} / \mathrm{L})$ as nitrogen sources. This medium, herein called control (CTRL), was used in the present study as a reference and the nitrogen sources (ammonium sulfate and yeast extract) were, initially, used in the same concentration to test, as carbon sources, the agro-industrial by-products $(10 \mathrm{~g} / \mathrm{L})$ individually: RFO_palm (residual frying oil from palm oil), RFO_ soy (residual frying oil from soybean oil), BWhey (butter whey), CWhey (cheese whey) and RWhey (ricotta whey).

Results obtained for cell growth and $\mathrm{pH}$ are presented in figure 1. Cell growth was higher for CTRL and RFO_soy, achieving around $7 \mathrm{~g}$ of cells (dry weight)/L at the end of the production process $(96 \mathrm{~h})$. The control medium profile is in accordance with the results of FONTES et al. (2010). It is a "rich" medium because of the presence of simple carbon sources and yeast extract as nitrogen and vitamin sources, which favors cell growth. Residual frying oil from soybean oil is also a good carbon source for a microorganism that produces lipase (NUNES et al., 2014). At this same time ( $96 \mathrm{~h})$, in RWhey medium, only $1 \mathrm{~g}$ of cells (dry weight)/L was detected, even with YE and AS, and for the other by-products (RFO 


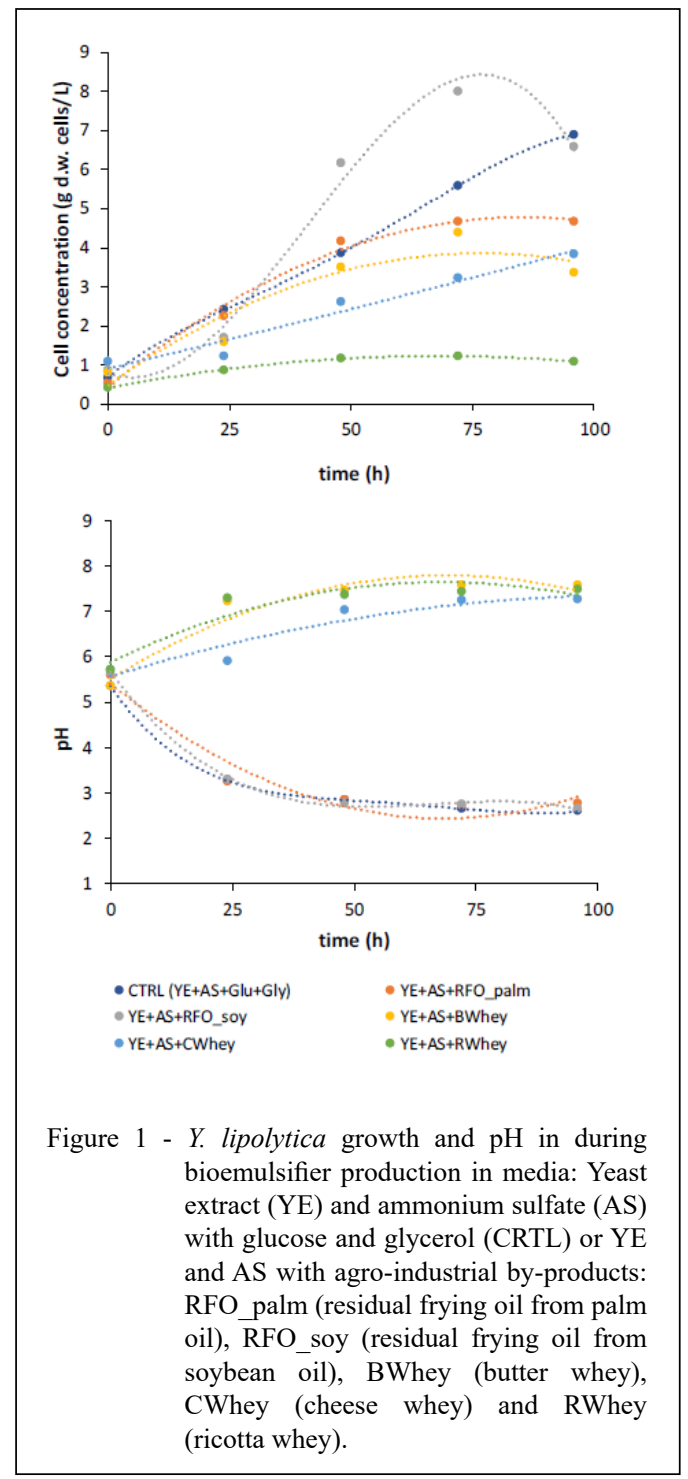

palm, BWhey, and CWhey) average values (3.5-4.5 $\mathrm{g}$ of cells (dry weight)/L) were obtained. The liquid solution remaining after ricotta separation (RWhey) has different characteristics than raw cheese whey due to both, the severe thermal treatment and the addition of acid salts (SANSONETTI et al., 2009). It contains lower amounts of protein, lipids, and energetic contents than the other dairy by-products (MENESES et al., 2019). This might be the reason for reduced cell growth. As for the $\mathrm{pH}$, an increase was observed for media containing dairy by-products, which might be related to the metabolization of these raw materials'protein content. On the contrary, for the CTRL and frying oil by-products, a reduction in $\mathrm{pH}$ was detected, usually related to the production of organic acids by this yeast (da SILVA et al., 2012). In the the oily residues, the metabolization of triacylglycerols present in the oil generates free fatty acids, which also reduces pH (NUNES et al., 2014). Medium $\mathrm{pH}$ is of great importance for biosurfactant production. BEDNARSKI et al. (2004) demonstrated that the acidity of the medium is a parameter related to the low production of biosurfactants. When studying the influence of $\mathrm{pH}$ on $Y$. lipolytica biosurfactant production, ZINJARDE \& PANT (2002) observed that the best productivity was obtained at $\mathrm{pH} 8.0$. Table 1 shows the increase in the emulsification index (EI) during $Y$. lipolytica growth in different media. Through a completely randomized factorial scheme, the effects of the production media and the fermentation time on EI were analyzed. Results obtained for the analysis of variance (ANOVA) are also shown in Table 1. Production medium (MEDIUM) and fermentation time (TIME) significantly $(p<0.05)$ influenced bioemulsifier production. The interaction between these two variables (MEDIUM $\mathrm{x}$ TIME) is also significant, which shows that these factors do not act independently.

Therefore, the Dunnett test was used to compare the EI of each medium for each time with the control (CTRL), and the Tukey test was also performed to verify differences in fermentation time for the same medium. These results are represented by * (Dunnett test) or a letter (Tukey test) after the EI value in Table 1. High emulsification index in the first $48 \mathrm{~h}(60.7 \%)$ was detected for the control medium, attesting that the medium optimized by FONTES et al. (2010), favors biosurfactant production. Bacillus sp. was tested for biosurfactant production, and ZHU et al. (2013) concluded that increased production also occurred with the use of glycerol and glucose as the carbon source. Values close to the control (CTRL) were only obtained after the third day of fermentation $(72 \mathrm{~h})$ for media containing residual frying oils (RFO_palm and RFO_soy) according to Dunnett test. The low $\mathrm{pH}$ found for these media (similar to the CTRL) did not favor bioemulsifier productivity.

Conversely, dairy by-products (butter and cheese whey) showed EI values statistically equal to the control (maximum individual values of $63.3 \%$ and $69.0 \%$, respectively) in the 96 -h culture period. CAGRI-MEHMETOGLU \& KUSAKLI (2012) showed that Bacillus subtillis ATCC6633 was able to consume lactose from whey, obtaining good biosurfactant production in 72 hours of culture. Ricotta whey was the only medium with a low emulsification index during the entire cultivation. A possible cause for the low EI, in this case, would 
Table 1 - Emulsification index during bioemulsifier production by $Y$. lipolytica and ANOVA for the evaluation of emulsification index (independent variables) in relation to fermentation time (TIME) and production medium (MEDIUM): Yeast extract (YE) and ammonium sulfate (AS) with glucose (Glu) and glycerol (Gly) (CRTL) or YE and AS with agro-industrial by-products: RFO_palm (residual frying oil from palm oil), RFO_soy (residual frying oil from soybean oil), BWhey (butter whey), CWhey (cheese whey) and RWhey (ricotta whey).

\begin{tabular}{|c|c|c|c|c|c|}
\hline \multirow[t]{2}{*}{ Production medium } & \multicolumn{5}{|c|}{ 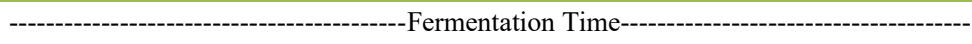 } \\
\hline & 0 & 24 & 48 & 72 & 96 \\
\hline CTRL (YE+AS+Glu+Gly) & $0^{\mathrm{c}}$ & $36.25^{\mathrm{b}}$ & $60.76^{\mathrm{a}}$ & $62.14^{\mathrm{a}}$ & $67.7^{\mathrm{a}}$ \\
\hline YE+AS+RFO_palm & $0^{\mathrm{c}}$ & $7.14^{* \mathrm{~b}}$ & $16.51^{* \mathrm{~b}}$ & $59.04^{\mathrm{a}}$ & $60.00^{\mathrm{a}}$ \\
\hline YE+AS+RFO_soy & $0^{\mathrm{b}}$ & $3.57^{* \mathrm{~b}}$ & $3.57^{* \mathrm{~b}}$ & $25.00^{\mathrm{a}}$ & $31.42^{\mathrm{a}}$ \\
\hline $\mathrm{YE}+\mathrm{AS}+\mathrm{BWhey}$ & $0^{c}$ & $24.28^{b c}$ & $46.66^{a b}$ & $60.71^{a b}$ & $63.33^{a}$ \\
\hline YE + AS+CWhey & $0^{\mathrm{c}}$ & $25.00^{\mathrm{b}}$ & $58.57^{\mathrm{a}}$ & $65.47^{\mathrm{a}}$ & $69.04^{\mathrm{a}}$ \\
\hline YE+AS+RWhey & $0^{\text {a }}$ & $3.57^{* a}$ & $34.52^{\mathrm{a}}$ & $18.75^{* a}$ & 10.71 *a \\
\hline \multicolumn{6}{|c|}{ 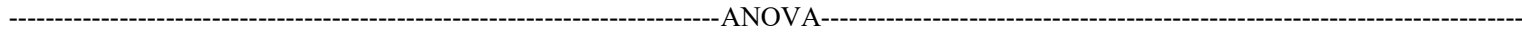 } \\
\hline SV & DF & SQ & MS & $\mathrm{F}$ & $p$-value \\
\hline Production medium (MEDIUM) & 5 & 10743.08 & 2148.62 & 29.2507 & 0.000000 \\
\hline Fermentation Time (TIME) & 4 & 22576.78 & 5644.20 & 76.8385 & 0.000000 \\
\hline MEDIUM x TIME & 20 & 6506.15 & 325.31 & 4.4286 & 0.000129 \\
\hline Residue & 30 & 2203.66 & 73.46 & & \\
\hline Total & 59 & 42029.67 & & & \\
\hline
\end{tabular}

SV: Sources of variation; DF: degree of freedom; SQ: sum of squares; MS: Mean square; F: fisher test; $p$-value: probability.

For emulsification index the number followed by $\left(^{*}\right)$ in the same column differ significantly (5\% probability) from the control by Dunnet's test.

For emulsification index the number followed by the same letter in the same line do not differ from each other ( $5 \%$ probability) by Tukey's test.

be the insufficient cell biomass since biosurfactant production depends on cell density.

Selection of agro-industrial by-products for bioemulsifier production with corn steep liquor and ammonium sulfate

The results show that agro-industrial wastes could replace glucose and glycerol. The next step was to replace yeast extract, an expensive input for large scale productions, by corn steep liquor (CSL). In this case, three CLS concentrations were tested $(1,3$, and $5 \mathrm{~g} / \mathrm{L})$, and the results are shown in figure 2 and table 2 .

Experiments showed reduced cell growth for CSL concerning yeast extract (data not shown). Media with glucose and glycerol (CTRL) and RFO soy were still the best for cell growth, except for the highest CSL concentration. Corn steep liquor probably does not supply specific compounds present in yeast extract that favor this yeast's growth. $\mathrm{pH}$ profiles were similar to those of media containing yeast extract (data are not shown), with an increase for the dairy by-products and reduction for the control (glucose and glycerol) and the residual oils.

EI values above $60 \%$ were detected for glucose and glycerol media with AS and CSL, for all CSL concentrations tested (Figure 2), as also observed for the yeast extract control (Figure 1), showing that the replacement was successful. Figure 2 also depicts null EI for RFO palm for 1 and $3 \mathrm{~g} / \mathrm{L}$ of CSL and low EI for RFO_soy. For the dairy by-products, high values of EI could be observed. These results were statistically evaluated, and the ANOVA is presented in table 2.

$$
\text { Production medium (MEDIUM), }
$$
fermentation time (TIME), and the interaction between MEDIUM, TIME, and CSL concentration ([CSL]) were significant ( $\mathrm{p}<0.05$ ) for EI, according to ANOVA (Table 2). The only variable that did not influence the response (EI)was [CLS]. Dunnett and Tukey tests were performed and are represented by * 


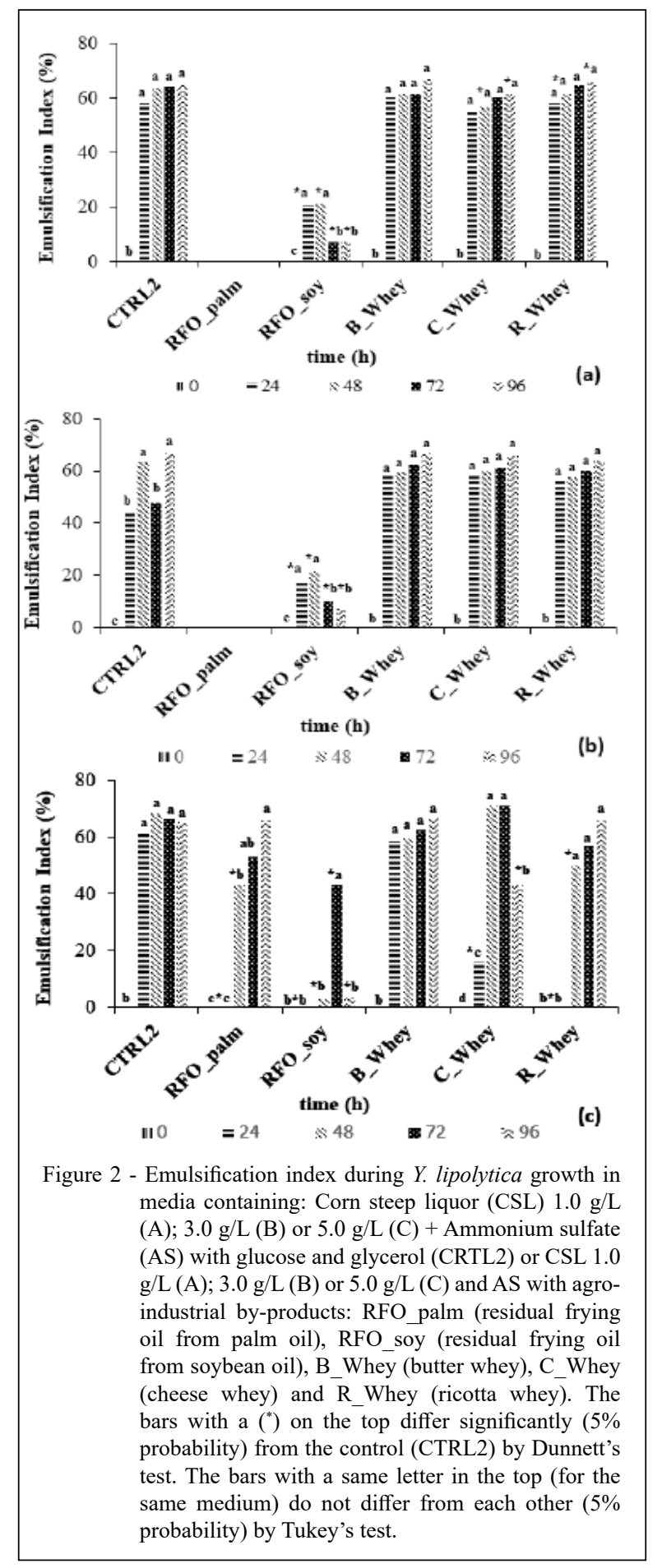

(Dunnett) and a letter (Tukey) in the top of the bars of Figure 3, making it possible to compare results considering the uncertainties of the values.

Statistically similar values compared to the control, which contained glycerol and glucose, were detected for BWhey, CWhey, and RWhey for all CSL concentrations tested. For the oily residues (RFO palm and RFO_soy), similar values to the control were only found at the end of the fermentation (72 - 96 h) for RFO_palm when $5 \mathrm{~g} / \mathrm{L}$ of CSL was used. 
Table 2 - ANOVA for the evaluation of emulsification index (independent variables) in relation to Corn steep licor concentration ([CSL]), fermentation time (TIME) and production medium (MEDIUM) for media containing: Corn steep liquor (CSL) $1.0 \mathrm{~g} / \mathrm{L}$ (A); 3.0 $\mathrm{g} / \mathrm{L}(\mathrm{B})$ or $5.0 \mathrm{~g} / \mathrm{L}$ (C) + Ammonium sulfate (AS) with glucose and glycerol (CRTL2) or CSL $1.0 \mathrm{~g} / \mathrm{L}$ (A); $3.0 \mathrm{~g} / \mathrm{L}$ (B) or 5.0 g/L (C) and AS with agro-industrial by-products: RFO_palm (residual frying oil from palm oil), RFO_soy (residual frying oil from soybean oil), BWhey (butter whey), CWhey (cheese whey) and RWhey (ricotta whey).

\begin{tabular}{lccccc}
\hline SV & DF & SQ & MS & F & -value \\
\hline Production medium (MEDIUM) & 5 & 48079.6 & 9615.9 & 940.40 & 0.000000 \\
\hline Fermentation time (TIME) & 4 & 48079.6 & 14045.1 & 1373.55 & 0.000000 \\
\hline Corn steep liquor concentration [CSL] & 2 & 56180.4 & 4.7 & 0.46 & 0.634532 \\
MEDIUM X TIME & 20 & 9.3 & 759.9 & 74.32 & 0.000000 \\
MEDIUM X [CSL] & 10 & 15198.9 & 1060.6 & 103.73 & 0.000000 \\
TIME X [CSL] & 8 & 10606.3 & 849.3 & 83.06 & 0.000000 \\
MEDIUM X TIME X [CSL] & 40 & 6794.8 & 216.0 & 21.12 & 0.000000 \\
Residue & 90 & 8639.0 & 10.2 & 26561.7 \\
\hline Total & 179 & 193587.9 & 2 & \\
\hline
\end{tabular}

SV: Sources of variation; DF: degree of freedom; SQ: sum of squares; MS: Mean square; F: fisher test; $p$-value: probability.

YILMAZ et al. (2009) had already described the potential of $Y$. lipolytica to produce biosurfactant from whey, by using whey wastewater from a farm milk factory. The biosurfactant produced presented high EI and reduction of surface tension. ANDRADE et al. (2015) observed that after $72 \mathrm{~h}$ maximum production of biosurfactant and reduction of surface tension by the yeast Candida glabrata (UCP1556) were possible when intermediate concentrations of corn steep liquor $(3 \%)$ and whey $(20 \%)$ were used. According to FONTES et al. (2012), microorganisms can use carbohydrates as a source of carbon and amino acids as sources of nitrogen for biosurfactant production. Therefore, it is suggested that $Y$. lipolytica was able to use whey as a nutrient, probably as a carbon source, as it is rich in lactose (carbohydrate) and corn steep

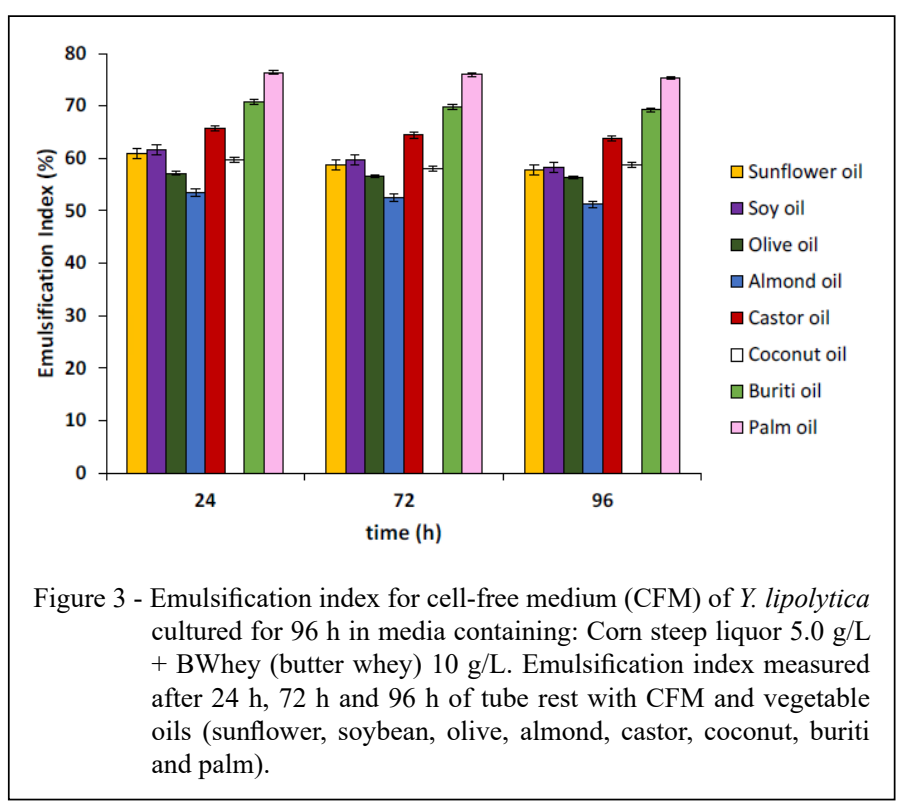

Ciência Rural, v.51, n.4, 2021. 
liquor as nitrogen source due to its high content of amino acids.

Between the dairy by-products, BWhey stood out because it showed similar results to the control (CTRL) for all conditions and fermentation times.

\section{Effect of corn steep liquor and ammonium sulfate in bioemulsifier production}

To understand the CSL and AS effects, these nitrogen sources were used alone (single nutrient sources in medium) and mixed to one another and compared to the addition of agro-industrial by-products.

No significant growth was observed in media containing CSL in three different concentrations $(1.0,3.0$ and $5.0 \mathrm{~g} / \mathrm{L})$ as the sole nutrient or together with AS (data not shown), implying that CSL in the concentrations studied is not a good nutrient source for cell growth, even when used together with AS. The low concentration of this nutrient, mainly a nitrogen source, may have contributed to the lack of cellular proliferation in these media. The $\mathrm{pH}$ profile was similar for all conditions studied, showing an increase (data are not shown). This increase might be related to nitrogen metabolism leading to the formation of ammonia. Cell growth was also not stimulated with ammonium sulfate as the sole nutrient source (data not shown). The $\mathrm{pH}$ profile shows an increase in $\mathrm{pH}$ values, indicating that the metabolization of AS also leads to ammonia formation. When agro-industrial by-products were used together with AS, cell growth was slightly higher for some of them (data are not shown), especially the oily sources. FONTES et al. (2012) also reported that the addition of AS to cashew apple juice, an agro-industrial by-product from cashew production, did not stimulate cell growth. The presence of CSL in those media was only positive for RFO_soy. The $\mathrm{pH}$ profile for media containing AS and agro-industrial by-products in the absence or the presence of CSL (data not shown) was similar to that of media with $\mathrm{YE}+\mathrm{AS}+$ agro-industrial by-products (Figure 1). The $\mathrm{pH}$ values increased for dairy by-products and decreased for oily residues, indicating that the generation of organic acids (free fatty acids) from the metabolism of triacylglycerols present in RFO influences $\mathrm{pH}$ reduction more than the metabolism of AS or CSL. Besides, the increase of $\mathrm{pH}$ value obtained with dairy by-products benefits bioemulsifier production, as already mentioned.

As the concentration of CSL was not significant for EI (in ANOVA, Table 2), [CSL] was fixed in average value in this comparison study. EI values for media containing only CSL or AS and with the agro-industrial by-products are shown in table 3 . As expected AS as the sole nutrient source was not able to induce biosurfactant production since it was not enough to promote cell growth. When the agroindustrial by-products were added to AS, only the dairy by-products revealed an induction to biosurfactant production. However, low EI values were obtained (EI below $30 \%$ ). With CSL Y. lipolytica could secrete biomolecules with emulsification activity, especially with the highest CSL concentration, reaching EI of 40 $\%$. Besides, when AS was added to CSL, EI values of almost $60 \%$ are depicted in table 3, showing that CSL was a good biosurfactant inducer. The CSL has been used in biosurfactant production media by several researchers with good results, most generally associated with a carbon source (LUNA et al., 2015; da SILVA et al., 2017; SANTOS et al., 2013; SILVA et al., 2014). Despite the high EI values for media containing AS and CSL, when the agro-industrial byproducts were added to AS+CSL, higher values were detected, particularly at lower fermentation times (48 h) (Table 3). BWhey, CWhey and RWhey were the best agro-industrial by-products tested. BWhey was also tested with CSL, without AS, in a medium that can be considered as low-cost since only contained agro-industrial by-products. This medium favored EI, as the values detected for all fermentation times (from $48 \mathrm{~h}$ to $96 \mathrm{~h}$ ) were the highest. Therefore, it was possible to obtain a high emulsification index with $Y$. lipolytica in media containing agro-industrial byproducts without supplementation. Literature reveals the use of several agro-industrial by-products for biosurfactant production by many microorganisms (SANTOS et al., 2013; SILVA et al., 2014; YILMAZ et al., 2009; da SILVA et al., 2017; LUNA et al., 2015; etc.). All of these references reported high values of surface tension reduction and EI, but the majority use supplements for agro-industrial media, as mineral medium and/or vitamin sources. The exclusive use of wastes is an advantage since it reduces cost and time for media preparation.

Additionally, the use of the residual liquid from butter or ricotta preparation, butter and ricotta whey, for biosurfactant production has not yet been reported in the literature. Cheese whey has long been used for several purposes (SISO, 1996) as well as for biosurfactant production nowadays (YILMAZ et al., 2009). Butter and ricotta whey, as inferior nutritional by-products, do not receive much attention (SANSONETTI et al., 2009). These dairy by-products (BWhey and RWhey) revealed to be good raw materials for bioemulsifier production by $Y$. lipolytica in the present study. 
Table 3 - Emulsification index during bioemulsifier production by $Y$. lipolytica in relation to fermentation time (TIME) and production medium (MEDIUM) for medium containing: AS (ammonium sulfate), CSL (corn steep liquor) $(1.0 \mathrm{~g} / \mathrm{L}, 3.0 \mathrm{~g} / \mathrm{L} \mathrm{or} 5 \mathrm{~g} / \mathrm{L}$ ), CSL $(1.0,3.0$ or $5.0 \mathrm{~g} / \mathrm{L}$ ) and AS (ammonium sulfate), ammonium sulfate with agro-industrial by-products: RFO_palm (residual frying oil from palm oil), RFO_soy (residual frying oil from soybean oil), BWhey (butter whey), CWhey (cheese whey) and RWhey (ricotta whey), ammonium sulfate, CSL and agro-industrial by-products: RFO_palm, RFO_soy, BWhey, CWhey and RWhey and only agro-industrial by-products (CSL 5.0g/L and BWhey).

\begin{tabular}{|c|c|c|c|c|c|}
\hline \multirow[t]{2}{*}{ Production medium } & \multicolumn{5}{|c|}{ 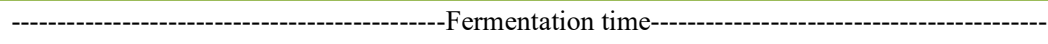 } \\
\hline & 0 & 24 & 48 & 72 & 96 \\
\hline AS & 0 & $0^{\mathrm{e}}$ & $0^{\mathrm{g}}$ & $0^{\mathrm{g}}$ & $0^{\mathrm{f}}$ \\
\hline CSL 1.0 & 0 & $0^{\mathrm{e}}$ & $0^{\mathrm{g}}$ & $32.05^{c}$ & $0^{f}$ \\
\hline CSL 3.0 & 0 & $0^{\mathrm{e}}$ & $32.05^{\mathrm{d}}$ & $20.71^{\mathrm{d}}$ & $0^{\mathrm{f}}$ \\
\hline CSL 5.0 & 0 & $0^{\mathrm{e}}$ & $30.95^{d}$ & $41.43^{b c}$ & $0^{\mathrm{f}}$ \\
\hline $\mathrm{CSL} 1.0+\mathrm{AS}$ & 0 & $0^{\mathrm{e}}$ & $44.00^{c}$ & $52.75^{b}$ & $57.00^{a b}$ \\
\hline CSL $3.0+$ AS & 0 & $20.96^{\mathrm{cd}}$ & $49.70^{\mathrm{bc}}$ & $36.80^{\mathrm{c}}$ & $57.87^{\text {ab }}$ \\
\hline CSL $5.0+\mathrm{AS}$ & 0 & $26.12^{b c}$ & $29.94^{\mathrm{d}}$ & $56.06^{b}$ & $15.34^{d}$ \\
\hline $\mathrm{AS}+\mathrm{RFO} \_$palm & 0 & $0^{\mathrm{e}}$ & $0^{g}$ & $0^{g}$ & $0^{\mathrm{f}}$ \\
\hline AS + RFO_soy & 0 & $0^{\mathrm{e}}$ & $0^{\mathrm{g}}$ & $0^{\mathrm{g}}$ & $0^{\mathrm{f}}$ \\
\hline AS + BWhey & 0 & $0^{\mathrm{e}}$ & $6.67^{\mathrm{f}}$ & $7.14^{\mathrm{f}}$ & $0^{\mathrm{f}}$ \\
\hline AS + CWhey & 0 & $0^{\mathrm{e}}$ & $6.9^{f}$ & $27.38^{\mathrm{cd}}$ & $0^{\mathrm{f}}$ \\
\hline AS + RWhey & 0 & $0^{\mathrm{e}}$ & $6.9^{f}$ & $13.81^{\mathrm{e}}$ & $0^{\mathrm{f}}$ \\
\hline $\mathrm{AS}+\mathrm{CSL}+\mathrm{RFO} \_$palm & 0 & $0^{\mathrm{e}}$ & $14.36^{\mathrm{e}}$ & $17.65^{\mathrm{de}}$ & $21.89^{c}$ \\
\hline $\mathrm{AS}+\mathrm{CSL}+\mathrm{RFO} \_$soy & 0 & $12.86^{\mathrm{d}}$ & $15.33^{\mathrm{e}}$ & $20.16^{d}$ & $5.95^{\mathrm{e}}$ \\
\hline $\mathrm{AS}+\mathrm{CSL}+\mathrm{BWhey}$ & 0 & $46.22^{a}$ & $56.37^{b}$ & $55.40^{b}$ & $66.33^{a}$ \\
\hline $\mathrm{AS}+\mathrm{CSL}+\mathrm{CWhey}$ & 0 & $42.94^{\mathrm{a}}$ & $62.57^{\mathrm{a}}$ & $64.50^{a}$ & $56.25^{b}$ \\
\hline $\mathrm{AS}+\mathrm{CSL}+\mathrm{RWhey}$ & 0 & $37.80^{\mathrm{ab}}$ & $54.74^{b}$ & $58.90^{\mathrm{ab}}$ & $63.51^{\mathrm{ab}}$ \\
\hline CSL 5.0 + BWhey & 0 & $0^{\mathrm{e}}$ & $66.27^{\mathrm{a}}$ & $64.70^{a}$ & $66.76^{\mathrm{a}}$ \\
\hline
\end{tabular}

For emulsification index the number followed by the same letter in the same column (same fermentation time) do not differ from each other ( $5 \%$ probability) by Tukey's test.

Vegetable oil-in-water emulsions with the bioemulsifier produced with BWhey and CSL

A practical way to verify biosurfactant applicability would be to determine its ability to convert immiscible liquids into stable emulsions (MAHANTY et al., 2006). Therefore, the cell-free medium obtained after 96 hours of $Y$. lipolytica cultivation in the medium containing BWhey (10 $\mathrm{g} / \mathrm{L})$ with $\mathrm{CSL}(5.0 \mathrm{~g} / \mathrm{L})$, herein called $Y l \mathrm{BWh}$ y emulsifier ( $Y$. lipolytica bioemulsifier produced from butter whey and steep corn liquor), was used to measure emulsification index with vegetable oils. Eight different vegetable oils (sunflower, soybean, olive, almond, castor, buriti, coconut and palm) were tested and measurements verified the stability of the emulsion after 24, 72, and $96 \mathrm{~h}$ (Figure 3).

$Y l$ BWhey emulsifier formed emulsions with all vegetable oils tested, with emulsification indexes higher than $50 \%$. Palm oil was the best emulsified organic phase with $Y l B W h e y$ emulsifier, while almond and olive oils were the poorest. All emulsions formed with the vegetable oils and YlBWhey emulsifier can be considered stable since EI values were maintained for $24 \mathrm{~h}, 72 \mathrm{~h}$, and $96 \mathrm{~h}$ (Figure 3). The emulsions formed were visually compact and remained stable for a month (30 days) at room temperature (data not shown).

Da SILVA et al. (2017) studied some hydrophobic compounds to evaluate the emulsification index of cell-free broth containing biosurfactant from Pseudomonas cepacia and high EI was obtained for motor oil, lubricating oil, and diesel, indicating an application for petroleum-based products. In contrast, for that biosurfactant, EI was low for soybean oil. DAVEREY \& PAKSHIRAJAN 
(2009) obtained better emulsification indices with vegetable oils (soybean oil, olive oil, sunflower oil, and mustard oil) when using sophorolipids produced by Candida bombicola. For the biosurfactant produced by $C$. lipolytica, the best emulsification indices were obtained for petroleum $(100 \%)$ and motor oil $(94 \%)$, while lower values were detected for corn and soybean oils (47\%) (SANTOS et al., 2013). The ability to produce an emulsion is related to the compatibility between the conformational structure of the biosurfactant and the hydrophobic compound, which will allow the microscopic drops to be stabilized or not (SILVA et al., 2014). In the present study, the cell-free media containing bioemulsifier produced by $Y$. lipolytica with only agro-industrial by-products, have shown good compatibility with vegetable oils to obtain oil-in-water emulsions. This result indicated a possible use of this bioemulsifier for food applications. For example, salad dressing is composed of vegetable oils, and usually, egg yolk is used as an emulsifying agent, but it has been partially substituted by other emulsifiers to reduce fat content and increase microbiological stability (RISCARDO et al., 2003).

\section{CONCLUSION}

High emulsification indices were detected in cell-free media obtained after $Y$. lipolytica growth in media containing residual frying oil or dairy byproducts (butter whey, cheese whey, or ricotta whey) as carbon sources and yeast extract and ammonium sulfate as vitamin and nitrogen sources. Yeast extract was successfully replaced by corn steep liquor (CSL), maintaining high emulsification indices in cell-free media. Butter whey (BWhey) was one of the best byproducts for bioemulsifier production by $Y$. lipolytica and the same emulsification index was achieved with its use with CSL, without any other component in the culture medium. Besides, the inoculum medium containing only these two raw materials could replace YPD "rich" medium, with the same EI during bioemulsifier production, which decreases production cost. This bioemulsifier, $Y l$ BWhey emulsifier, showed good EI for vegetable oil-in-water emulsions, indicating possible application in the food industry.

\section{ACKNOWLEDGEMENTS}

The financial support of Fundação Carlos Chagas Filho de Amparo à Pesquisa do Estado do Rio de Janeiro (FAPERJ), Coordenação de Aperfeiçoamento de Pessoal de Nível Superior (CAPES) and Conselho Nacional de Desenvolvimento Científico e Tecnológico (CNPq), is greatly acknowledged. F. dos Santos and A. Pereira received Ph.D. scholarship from CAPES. P Amaral received a scholarship from $\mathrm{CNPq}$ (Bolsa Produtividade em pesquisa 308626/2019-2). MH Rocha-Leão received scholarship from $\mathrm{CNPq}$ (Bolsa de Produtividade em Desenvolvimento Tecnológico e Extensão Inovadora - DT). The authors would like to thank the company Ingredion Brazil for the donation of corn steep liquor.

\section{DECLARATION OF CONFLICTS OF INTERESTS}

The authors declare no conflict of interest. The founding sponsors had no role in the design of the study; in the collection, analyses, or interpretation of data; in the writing of the manuscript, and in the decision to publish the results.

\section{AUTHORS' CONTRIBUTIONS}

Conceptualization: P.F.F. Amaral (PFFA), M.H.M. Rocha-Leão (MHRL), G.C. Fontes-Sant'Ana (GCF); Data curation: PFFA; Formal analysis: A.S. Pereira (ASP), F.F. dos Santos (FFS); Funding acquisition: PFFA, MHRL; Investigation: K.M.L. Freitas (KMLF), FFS; Methodology: FFS, PFFA; Project administration: PFFA; Resources: PFFA, MHRL, GCF; Software ASP; Supervision: PFFA, MHRL, GCF; Validation: ASP; Visualization: FFS, PFFA; Roles/Writing - original draft: FFS; Writing - review \& editing: PFFA, GCF.

\section{REFERENCES}

AMARAL, P. F. F. et al. Production and characterization of a bioemulsifier from Yarrowia lipolytica. Process Biochemistry, v.41, p.1894-1898, 2006. Available from: <https://doi. org/10.1016/j.procbio.2006.03.029>. Accessed: Nov. 6, 2019. doi: 10.1016/j.procbio.2006.03.029.

ANDRADE R. F. S. et al. Enhanced roduction of an Glycolipid Biosurfactant Produced by Candida glabrata UCP/WFCC1556 for Application in Dispersion and Removal of Petro derivatives. Int. J. Curr. Microbiol. Appl. Sci., v.4, n.7, p.563-576, 2015. Available from: $\quad<$ https://www.semanticscholar.org/paper/EnhancedProduction-of-an-Glycolipid-Biosurfactant-Antunes-Lima/78c 2 5371ef28b6d126f8b7e72de4345103dba201>. Accessed: Nov. 6, 2019. doi: Corpus ID: 54013361.

BEDNARSKI, W.; Aet al.,Application of oil refinery waste in the biosynthesis of glycolipids by yeast. Bioresource Technology, n.95, p.15-18, 2004. Available from: <https://doi.org/10.1016/j. biortech.2004.01.009>. Accessed: Nov. 6, 2019. doi: 10.1016/j. biortech.2004.01.009.

CAGRI-MEHMETOGLU, A.; KUSAKLI, S. Production of polysaccharide and surfactin by Bacillus subtilis ATCC 6633 using rehydrated whey powder as the fermentation medium. Journal Dairy Science, v.95 (7), 3643-3649, 2012. Available from: <https://doi.org/10.3168/jds.2012-5385>. Accessed: Nov. 18, 2019. doi: $10.3168 /$ jds.2012-5385.

DARVISHI, F. et al. Production and structural modeling of a novel asparaginase in Yarrowia lipolytica. International Journal of Biological Macromolecules, v.125, p.955-961, 2019. Available from: < https://doi.org/10.1016/j.ijbiomac.2018.12.162>. Accessed: Nov. 6, 2019. doi: 10.1016/j.ijbiomac.2018.12.162. 
da SILVA, L. V. et al. Production of citric acid by Yarrowia lipolytica in Different Crude Glycerol Concentrations and in Different Nitrogen Sources. Chemical Engineering transactions, v.27, p.199-204, 2012. Available from: <https://doi.org/10.3303/ CET1227034>. Accessed: Nov. 18, 2019. doi: 10.3303/ CET1227034.

da SILVA, R.C.F.S. et al. Production and characterization of a new biosurfactant from Pseudomonas cepacia grown in low-cost fermentative medium and its application in the oil industry. Biocatalysis and Agricultural Biotechnology, v.12, p.206-215, 2017. Available from: <https://doi.org/10.1016/j. bcab.2017.09.004>. Accessed: Nov. 6, 2019. doi: 10.1016/j. bcab.2017.09.004

DAVEREY, A.; PAKSHIRAJAN, K. Production of sophorolipids by the yeast Candida bombicola using simple and low cost fermentative media. Food Research International, v.42, p.499-504, 2009. Available from: <https://doi.org/10.1016/j. foodres.2009.01.014>. Accessed: Nov. 6, 2019. doi: 10.1016/j. foodres.2009.01.014

FONTES, G. C. et al. Factorial design to Optimize Biosurfactant Production by Yarrowia lipolytica. Journal of Biomedicine and Biotechnology. 2010. Available from: $<$ http://dx.doi. org/10.1155/2010/821306>. Accessed: Oct. 10, 2019. doi: $10.1155 / 2010 / 821306$

FONTES, G. C. et al. Renewable resources for Biosurfactant Production by Yarrowia lipolytica. Brazilian Journal of Chemical Engineering. v.29, p.483-493, 2012. Available from: <http:// dx.doi.org/10.1590/S0104-66322012000300005>. Accessed: Oct. 10, 2019. doi: 10.1590/S0104-66322012000300005.

FRAGA, J. et al. Green (Detox) juice physicochemical properties and stabilization effect of naturals emulsifiers. Cienc. Rural, Santa Maria, v.50, n.3, e20190739, 2020. Available from <http:// www.scielo.br/scielo.php? script $=$ sci_arttext\&pid $=$ S0103$84782020000300752 \& \operatorname{lng}=$ en $\& n r m=$ iso $>$. Accessed: Apr. 7, 2020 doi: 10.1590/0103-8478cr20190739.

GUDINA, E. J. et al. Biosurfactants produced by marine microorganisms with therapeutic applications. Mar Drugs, v.14, n.2, p.38, 2016. Available from: <https://doi.org/10.3390/ md14020038>. Accessed: Nov. 6, 2019. doi: 10.3390/md14020038.

HAGLER, A.N.; MENDONÇA-HAGLER, L.C. Yeasts from marine and an estuarine water with different levels of pollution in the state of Rio de Janeiro, Brazil. Applied Environmental Microbiology, v.41, n.1, p.173-178, 1981. Available from: $<$ https://aem.asm.org/content/41/1/173.short>. Accessed: Nov. 8, 2019. doi: PMCID: PMC243658.

LIU, X. et al. Citric acid production by Yarrowia lipolytica SWJ$1 \mathrm{~b}$ using corn steep liquor as a source of organic nitrogen and vitamins. Industrial Crops and Products, v.78, p.154-160, 2015. Available from: <https://doi.org/10.1016/j.indcrop.2015.10.029> Accessed: Nov. 18, 2019. doi: 10.1016/j.indcrop.2015.10.029.

LUNA, J. M. et al. Characterization, surface properties and biological activity of a biosurfactant produced from industrial waste by Candida sphaerica UCP0995 for application in the petroleum industry. Colloids and Surfaces B: Biointerfaces, v.102, p.202-209, 2013. Available from: $<$ https://doi.org/10.1016/j. colsurfb.2012.08.008>. Accessed: Nov. 18, 2019. doi: 10.1016/j. colsurfb.2012.08.008.
LUNA, J. M. et al. Environmental applications of the biosurfactant produced by Candida sphaerica cultivated in low-cost substrates. Colloids and Surfaces A: Physicochem. Eng. Aspects, v.480, p.413-418, 2015. Available from: <https://doi.org/10.1016/j. colsurfa.2014.12.014>. Accessed: Nov. 18, 2019. doi: 10.1016/j. colsurfa.2014.12.014

LUNA, J. M.et al. Production of biosurfactant from Candida bombicola URM 3718 for environmental applications. Chemical Engineering Transactions, 49, p.583-588, 2016. Available from: $<$ https://doi.org/10.3303/CET1649098>. Accessed: Nov. 6, 2019. doi: 10.3303/CET1649098.

MAHANTY, B. et al. Production and properties of a biosurfactant applied to polycyclic aromatic hydrocarbon solubilization. Applied Biochemistry and Biotechnology, v.134, n.2, p.129-141, 2006. Available from: <https://doi.org/10.1385/ABAB:134:2:129>. Accessed: Nov. 6, 2019. doi: 10.1385/ABAB:134:2:129.

MAKKAR, R. S. et al. Advances in utilization of renewable substrates for biosurfactant production. Applied Microbiology Biotechnology Express, v.1, p.1-19, 2011. Available from: <https://doi.org/10.1186/2191-0855-1-5>. Accessed: Nov. 18, 2019. doi: 10.1186/2191-0855-1-5.

MARQUES, N.S. et al. Eco-friendly Bioemulsifier Production by Mucor circinelloides UCP0001 Isolated from Mangrove Sediments Using Renewable Substrates for Environmental Applications. Biomolecules, v.10, n.3, p.365, 2020. Available from: <https:// doi.org/10.3390/biom10030365>. Accessed: Mar. 16, 2020. doi: $10.1186 / 2191-0855-1-5$

MARTINS, P. C.; MARTINS, V. G. Biosurfactant production from industrial wastes with potential remove of insoluble paint. International Biodeterioration \& Biodegradation, v.127, p.10-16, 2018. Available from: <https://doi.org/10.1016/j. ibiod.2017.11.005>. Accessed: Nov. 18, 2019. doi: 10.1016/j. ibiod.2017.11.005.

MENESES, R. B. et al. Effect of dairy by-products as milk replacers on quality attributes of ice cream. Journal of Dairy Science, v.103, p.10022-10035, 2020. Available from: <https:// doi.org/10.3168/jds.2020-18330>. Acessed: Oct. 30,2020. doi: $10.3168 /$ jds.2020-18330.

MENESES, R. B. Diary by-products used as ingredients to ice cream. 2019. 183f. Thesis (PhD in Food Science) Instituto de Química, Universidade Federal Rio de Janeiro.

PI, Y. et al. Microbial degradation of four crude oil by biosurfactant producing strain Rhodococcus sp. Bioresource Technology, v.232, p.263-269, 2017. Available from: $<$ https://doi.org/10.1016/j. biortech.2017.02.007>. Accessed: Nov. 6, 2019. doi: 10.1016/j. biortech.2017.02.007

NUNES, P. M. B. et al. Intracellular Lipase Production by Yarrowia lipolytica Using Different Carbon Sources. Chemical Engineering Transactions, v.38, p.421-426, 2014. Available from: $<$ https://doi. org/10.3303/CET1438071>. Accessed: Nov. 6, 2019. doi: 10.3303/ CET1438071.

RADZUAN, M. N. et al. Production and characterization of rhamnolipid using palm oil agricultural refinery waste. Bioresource Technology, 225, p.99-105, 2017. Available from: <https://doi. org/10.1016/j.biortech.2016.11.052>. Accessed: Nov. 6, 2019. doi: 10.1016/j.biortech.2016.11.052. 
RAMÍREZ, J. M. et al. Rhamnolipid and surfactin production from olive oil mill waste as sole carbon source. Bioresource Technology, 198, p.231-236, 2015. Available from: $<$ https://doi. org/10.1016/j.biortech.2015.09.012>. Accessed: Nov. 6, 2019. doi: 10.1016/j.biortech.2015.09.012.

RISCARDO, M.A. et al. Gallegos, Influence of composition of emulsifier blends on the rheological properties of salad dressingtype emulsions. Food Science and Technology International, v.9, n.1, p.53-63, 2003. Available from: <https://doi.org/10.1 177/1082013203009001008>. Accessed: Nov. 6, 2019. doi: $10.1177 / 1082013203009001008$.

SANSONETTI, S. et al. Bio-ethanol production by fermentation of ricotta cheese whey as an effective alternative non-vegetable source. Biomass Bioenergy, v.33, n.12, p.1687-1692, 2009. Available from: $<$ https://doi.org/10.1016/j.biombioe.2009.09.002>. Accessed: Nov. 18, 2019. doi: 10.1016/j.biombioe.2009.09.002.

SANTOS, et al. Synthesis and evaluation of biosurfactant produced by Candida lipolytica using animal fat and corn steep liquor. Journal of Petroleum Science and Engineering, v.105, p.43-50, 2013. Available from: <https://doi.org/10.1016/j. petrol.2013.03.028>. Accessed: Nov. 18, 2019. doi: 10.1016/j. petrol.2013.03.028.

SILVA, E. J. et al. Characterization of a biosurfactant produced by Pseudomonas cepacian CCT6659 in the presence of industrial wastes and its application in the biodegradation of hydrophobic compounds in soil. Colloids and Surfaces B: Biointerfaces, v.117, p.36-41, 2014. Available from: <https://doi.org/10.1016/j. colsurfb.2014.02.012>. Accessed: Nov. 6, 2019. doi: 10.1016/j. colsurfb.2014.02.012.

SINGH, A., HA et al.,Surfactants in microbiology andbiotechnology: Part 2. Application aspects. Biotechnology Advances, v.25, p.99-121, 2007. Available from: <https://doi. org/10.1016/j.biotechadv.2006.10.004>. Accessed: Nov. 18, 2019. doi: 10.1016/j.biotechadv.2006.10.004.

SISO, M. G. The biotechnological utilization of cheese whey: a review. Bioresource technology v.57, n.1, p.1-11, 1996 Available from: $<$ https://doi.org/10.1016/0960-8524(96)00036-3>. Accessed: Nov. 18, 2019. doi: 10.1016/0960-8524(96)00036-3.

SOUZA, K. S. T. et al. New glycolipid biosurfactants produced by the yeast strain Wickerhamomyces anomalus CCMA 0358. Colloids and Surfaces B: Biointerfaces, 154 p.373-382, 2017. Available from: $<$ https://doi.org/10.1016/j.colsurfb.2017.03.041>. Accessed: Nov. 18, 2019. doi: 10.1016/j.colsurfb.2017.03.041.

UZOIGWE, C.; et al.,. Bioemulsifiers are not biosurfactants and require different screening approaches. Frontiers in Microbiology, v.6, 2015. Available from: <https://doi.org/10.3389/fmicb.2015.00245>. Accessed: Nov. 6, 2019. doi: 10.3389/fmicb.2015.00245.

YILMAZ, F. et al. Production and characterization of biosurfactants produced by microorganisms isolated from milk factory wastewaters. Environmental Technology, v.30, n.13, p.1397-1404, 2009. Available from: <https://doi. org/10.1080/09593330903164528>. Accessed: Nov. 6, 2019. doi: $10.1080 / 09593330903164528$.

ZHU,Z. et al. The usage of rice straw as a major substrate for the production of surfactin by Bacillus amyloliquefaciens XZ-173 in solid-state fermentation. Journal Environmental Management, v.127, 96-102, 2013. Available from: <https://doi.org/10.1016/j.jenvman.2013.04.017>. Accessed: Nov. 6, 2019. doi:10.1016/j.jenvman.2013.04.017.

ZINJARDE, S. S.; PANT, A. Emulsifier from a tropical marine yeast, Yarrowia lipolytica NCIM 3589. Journal Basic Microbiology. v.42, p.67-73, 2002. Available from: $<$ https://doi.org/10.1002/15214028(200203)42:1<67::AID-JOBM67>3.0.CO;2-M>. Accessed: Nov. 6, 2019. doi: 10.1002/1521-4028(200203)42:1<67::AIDJOBM67>3.0.CO;2-M. 